DOI: 10.17805/trudy.2017.5.9

\title{
ИЗ ИСТОРИИ КРЕСТЬЯНСКОЙ ВОЙНЫ 1670-1671 гг. НА ТЕРРИТОРИИ МОРДОВИИ: БИОГРАФИЯ ПАВЛА ЕЛУШЕВА
}

\author{
А. А. Инков \\ Московский гуманитарный университет
}

Аннотация: В статье рассматриваются малоизвестные страницы крестьянской войны 1670-1671 г2. на территории Мордовии на примере действий отряда атамана П. Елушева. На основе сохранившихся документов прослеживается биография Елушева до начала Разинского восстания. Вопреки распространенному в историографии мнению о происхождении мордовского атамана из крестьян, источники свидетельствуют о его принадлежности к служилому сословию.

Ключевые слова: Крестьянская война; Павел Елушев; крестьяне; Мордовия; история России

\section{FROM THE HISTORY OF THE PEASANT WAR OF 1670-1671 IN MORDOVIA: PAVEL YELUSHEV'S BIOGRAPHY}

\author{
A. A. Inkov \\ Moscow University for the Humanities
}

Abstract: The article deals with little-known pages of the Peasant War of 1670-1671 on the territory of Mordovia, exemplified by the actions of ataman P. Yelushev's troop. On the basis of the surviving documents, Yelushev's biography can be traced be-fore the start of the Razin rebellion. Contrary to the opinion, popular in histori-ography, about the peasant origin of the Mordovian ataman, the sources indicate his affiliation with the military stratum.

Keywords: Peasant War, Pavel Yelushev, peasants, Mordovia; history of Russia

Крестьянская война под руководством С. Т. Разина на территории Мордовского края оставила нам целую плеяду имен атаманов восставших крестьян - А. Осипова, Я. Никитинского, А. Арзамасской, А. Боляева, П. Елушева, М. Харитонова, Ф. Сидорова и др. К сожалению, сведения о сподвижниках С. Т. Разина сохранились исключительно в изложении проправительственных, враждебно настроенных к восставшим, источников. Содержавшиеся в них известия носят большей частью фрагментар- 
ный характер, посвящены короткому, протяженностью всего в несколько месяцев, периоду их деятельности. Вследствие этого, если об одних из крестьянских атаманов сегодня можно написать целые книги, то о жизни других историкам почти ничего неизвестно, кроме их имен.

Павлу Елушеву, уроженцу с. Шугурово, возглавившему в период Разинского восстания в восточных районах Мордовии отряд восставших крестьян, в этом плане повезло меньше всего. О нем известно так мало, что в большинстве работ по истории Крестьянской войны на территории Мордовского края его имя почти никогда не упоминается.

Считается, что в источниках того времени о П. Елушеве сохранилось всего два известия. Первое из них датируется сентябрем 1670 г., т. е. самым началом Крестьянской войны в Мордовии. В это время мордовские земли становятся ареной ожесточенных столкновений между правительственными войсками и отрядами восставших казаков и крестьян. Несмотря на то, что эти бои носили локальный характер, очевидна их связь с другим важнейшим событием Крестьянской войны - осадой войсками С. Т. Разина Симбирска. Стремясь к овладению этим стратегически важным городом Поволжья, руководство повстанческой армии пыталось расширить район восстания с тем, чтобы не только численно увеличить свои силы, но и создать в тылу правительственных войск новый очаг восстания, чтобы затруднить переброску царским правительством подкреплений на помощь осажденному разинцами Симбирску.

С этой целью в начале осени 1670 г. С. Т. Разин направил из-под Симбирска в восточные районы Мордовии несколько отрядов казаков и крестьян. Продвигаясь от уезда к уезду, они должны были поднимать жившее в них население на борьбу против помещиков. Один из таких отрядов во главе с казачьим атаманом М. Харитоновым в сентябре развернул военные действия против правительственных войск вдоль Саранско-Атемарской сторожевой черты и в Саранском уезде. Задавленное непосильными налогами и многочисленными притеснениями царской администрации население края повсеместно переходило на его сторону. Закрепившись в восточных районах сторожевой черты, М. Харитонов со своим отрядом пошел дальше на запад, к Саранску. 17 сентября 1670 г. восставшие заняли Атемар, а спустя два дня на их сторону перешел и Саранск. К концу того же месяца восстанием был охвачен весь Саранский уезд и ряд соседних уездов. Восставшие уничтожали органы воеводского управления, расправлялись с неугодными представителями местной администрации, грабили помещичьи усадьбы. В занятом разинцами Саранске было сформировано повстанческое правительство во главе с Я. Никитинским.

В этот же период на востоке Саранского уезда начинает действовать и отряд мордовских и русских крестьян во главе с П. Елушевым. Локали- 
зация действий отряда в районе современного с. Шугурово, отмечаемая всеми без исключения исследователями Крестьянской войны, позволяет считать, что П. Елушев, очевидно, был уроженцем этого села. Население Шугурова и тогда, и сегодня было мордовским по своему национальному составу, из чего можно заключить, что мордвином был и сам П. Елушев. Находясь в тесной связи с повстанческим правительством в Саранске, отряд П. Елушева действовал в стратегически важном районе Саранского уезда, поскольку здесь вдоль Сурского леса проходила одна из двух дорог, связывавших Саранск с Симбирском.

Октябрь - ноябрь 1670 г. - время наивысшего подъема Крестьянской войны в Саранском уезде. В это время на территории уезда действует целый ряд повстанческих отрядов, возглавляемых А. Боляевым, Я. Никитинским, П. Елушевым и другими казацкими и крестьянскими атаманами. Подробности военных действий шугуровского атамана в рассматриваемый период известны, в основном, применительно к общим событиям, происходившим в восточных районах Мордовского края.

Второй раз имя Павла Елушева во время Разинского восстания упоминается уже в его финальный, самый трагический период. После взятия 18 декабря 1670 г. правительственными войсками Саранска, в его окрестностях началась расправа над руководителями и участниками повстанческого движения. Сохранилась отписка полкового воеводы, князя Ю. Долгорукова, направленная в Приказ Казанского дворца с подробностями подавления восстания по Саранской черте. Из нее мы узнаем, что 23 декабря 1670 г. скрывавшийся в окрестностях Саранска П. Елушев был схвачен татарами Терентьевской сотни из полка Лихутина и доставлен в город, где предан воеводскому суду. Далее Ю. Барятинский сообщал, что П. Елушев «ходил с мордвою атаманом и с воровскими казаками на всех боях был». Вследствие доказанности вины шугуровского атамана в участии в мятеже, воевода написал, что «он де, велел того вора Пошатка повесить» (Крестьянская война ..., 1951: 463).

Несмотря на всю краткость данного известия о П. Елушеве, отписка Долгорукова содержит весьма важные сведения о деятельности шугуровского воеводы в период Крестьянской войны в Саранском уезде. Сообщение царского воеводы о том, что П. Елушев со своим отрядом «на всех боях был», позволяет считать его активным участником таких крупнейших сражений повстанцев с царскими войсками в восточной Мордовии, как битвы у деревни Кондорать, сел Баево и Тургенево.

Первое из этих сражений произошло 12 ноября 1670 г. у деревни Кондорать, где силы повстанцев во главе с Акаем Боляевым столкнулись с царскими полками воеводы князя Ю. Барятинского, выступившими после разгрома армии С. Т. Разина под Симбирском для подавления по- 
встанческого движения в мордовских землях. 15-тысячное войско восставших, объединившее отряды А. Боляева, Я. Никитинского, А. Осипова, А. Савельева и других казачьих и крестьянских атаманов, атаковало правительственные войска, но в ходе завязавшегося сражения было разбито и отступило к Саранску (там же: 302).

Однако это поражение не остановило восставших. Собрав через несколько недель новую армию, лидеры повстанцев снова попытались перехватить инициативу. Воспользовавшись тем, что после победы под Кондоратью, царские воеводы разделили свои силы, разинцы решили разбить своих противников по частям. Армия восставших во главе с А. Боляевым двинулась на Алатырь. 7 декабря в районе деревни Баево восставшие столкнулись с правительственными войсками, возглавляемыми опытным воеводой В. Паниным. Вспыхнувшее между ними сражение с переменным успехом продолжалось весь день и не принесло успех ни одной из сторон. Понеся в бою большие потери, к ночи А. Боляев отвел отряды восставших казаков и крестьян к соседнему селу Тургенево. Тем временем на помощь царскому воеводе В. Панину подошли конные и пешие полки князя Ю. Барятинского, в рядах которых было много иностранных наемников. Объединив свои силы, царские воеводы двинулись следом за восставшими. На рассвете прерванная между сторонами битва возобновилась с новой силой. Как и предыдущее сражение, оно продолжалось весь день. К ночи плохо вооруженные и организованные войска восставших, наконец, были сломлены и обратились в бегство. Воеводы захватили на поле боя 20 пушек и 68 знамен восставших (там же: 462).

Остатки крестьянских отрядов отступили к Саранску. Каратели, двигавшиеся за ними, сжигали крестьянские деревни, вешали захваченных в плен участников восстания. Жители замиренных правительственными воеводами деревень обязаны были приносить присягу на верность царю.

Как следует из отписки Ю. Долгорукова, в отличие от большинства повстанцев, после поражения у деревни Тургенево разбежавшихся по домам и прекративших сопротивление карателям, П. Елушев вместе с другими лидерами восставших продолжил вести упорную борьбу против царских полков. Вступив в Шугурово и узнав, что П. Елушев отказался присягать на верность царю, воевода В. Панин приказал сжечь его родную деревню.

Последний очаг сопротивления правительственным силам в восточных и центральных районах Мордовии возник в Саранске и его окрестностях. Борьба восставших с царскими воеводами здесь продолжалась вплоть до падения Саранска в конце декабря 1670 г. Скрывавшиеся после поражения в его окрестностях многие руководители и участники повстанческого движения были пленены и преданы казни. 20 декабря в своей родной деревне Костяшево карателями был арестован руководи- 
тель Крестьянской войны в восточной Мордовии А. Боляев. Спустя 3 дня, 23 декабря был схвачен и отправлен в Саранск П. Елушев. После допроса и пыток разинские атаманы были преданы казни.

Так кем же был по своему происхождению шугуровский атаман? В работах, посвященных Разинскому восстанию на территории Мордовии, нередко утверждается, что большинство предводителей восставших были выходцами из крестьянской среды. Однако эти выводы являются не совсем верными. Крестьянами по своему происхождению из них были всего лишь единицы. Да и для того, чтобы организовать большие массы восставших, возглавить их, руководить военными действиями, командовать тысячами ратников на поле боя, требовались специальные военные знания, которым просто неоткуда было взяться у неграмотных, задавленных тяжелым феодальным гнетом крепостных крестьян. Особенность Крестьянской войны в восточной Мордовии заключалась в том, что силы разинцев в этом районе возглавляли прежде всего лица, в той или иной степени связанные с военной средой, служилые люди по прибору, которые до войны во множестве служили на Саранско-Атемарской сторожевой черте. Не случайно именно на этой черте располагался главный очаг восстания в восточной Мордовии.

Сохранившиеся материалы Симбирской приказной избы не оставляют сомнения в том, что П. Елушев как раз и принадлежал к таким людям. Обнаруженный нами документ представляет собой извлечение из расходной книги приказной избы г. Симбирска за июнь 1667 г. Это третье известие о шугуровском атамане, сохранившееся в источниках. Важность его заключается в том, что в отличие от предыдущих двух известий, оно датируется временем до начала Крестьянской войны на территории Мордовии. Документ содержит запись о том, что «... (в июне 1667 г.) Саранского уезду, деревни Шугуровы, (Симбирской приказной избой. - А. И.) мордвину Бошатке Елушеву на хлеб 6 алтын, 4 деньги дано, послан он Бошатка, в степь за изменники башкирцы с карпом Оникеевым, в вожах» (Документы и материалы ..., 1940: 323).

К сожалению, подробности этой поездки нам неизвестны. Однако, из документа, вполне можно заключить, что П. Елушев, до своей участия в Разинском восстании, находился на государевой службе. Можно предполагать, что он был приписан к одному из гарнизонов Корсунско-Симбирской сторожевой черты или Саранско-Атемарской черты, построенных царским правительством в конце XVI - середине XVII в. для защиты восточных границ Российского государства от набегов крымских и ногайских татар.

Из записи расходной книги приказной избы следует, что П. Елушев не мог быть крестьянином, как полают некоторые исследователи (Чистякова, Соловьев, 1986: 153; История Мордовии ... , 2001: 141). Вряд ли про- 
стому крестьянину или рядовому стрельцу стали поручать бы выполнения такого сложного и ответственного задания, как поимка убежавших с государевой службы башкирцев. В то же время, из документа ясно, что П. Елушев, по-видимому, не принадлежал и к высшему командному составу гарнизонных войск. В пользу данного предположения говорит прежде всего незначительность выделенного ему властями на время похода содержания в 6 алтын 4 деньги. Обычное содержание в дороге дворян и детей боярских, занимавших привилегированное положение в служилой среде, в то время было гораздо большим.

С учетом вышеизложенного, в целом, можно с большой долей вероятности утверждать, что П. Елушев был представителем мелкой служилой знати, возможно, однодворцем. Нет сомнений, что будущий шугуровский атаман был хорошо знаком с военным делом, имел за плечами богатый опыт царской службы, обладал недюжинными организаторскими способностями. Именно эти качества выдвинули П. Елушева уже в первые месяцы Крестьянской войны на роль атамана восставших крестьян.

\section{СПИСОК ЛИТЕРАТУРЫ}

История Мордовии: С древнейших времен до середины XIX века (2001). Саранск: Изд-во Мордов. ун-та. 344 с.

Документы и материалы по истории Мордовской АССР (1940) : сборник документов : в 4-х т. Саранск: МНИИЯЛИ, Мордов. гос. изд-во, Мордов. кн. изд-во. Т. І. 435 с.

Крестьянская война под предводительством С. Т. Разина (1957) : сборник документов : в 3-х т. М. : Изд-во АН СССР. Т. ІІ. Август 1670 - январь 1671. Ч. I. 665 с.

Чистякова, Е. В., Соловьев, В. М. (1986) Разин и разинцы на Мордовской земле. Саранск: Мордовское книжное изд-во. 112 с.

Дата поступления: 10.12.2017 2.

Инков Александр Александрович - кандидат исторических наук, доцент, доцент кафедры истории и региоведения Московского гуманитарного университета. Адрес: 111395 , Россия, г. Москва, ул. Юности, д. 5. Тел.: +7 (499) 374-55-81. Эл. адрес: antigon1922@yandex.ru

Inkov Aleksandr Aleksandrovich, Candidate of History, Associate Professor, Associate Professor, Department of History and Regional Studies, Moscow University for the Humanities. Postal address: 5, Yunosti St., Moscow, Russian Federation 111395. Tel.: +7 (499) 374-55-81.E-mail: antigon1922@yandex.ru 


\section{Для цитирования:}

Инков А. А. Из истории крестьянской войны 1670-1671 гг. на территории Мордовии: биография Павла Елушева [Электронный ресурс] // Научные труды Московского гуманитарного университета. 2017. № 6. URL: http://journals.mosgu.ru/trudy/article/ view/625 (дата обращения: дд.мм.гг.). DOI: 10.17805/trudy.2017.6.9 